\title{
Клочковська В.O.
}

кандидат економічних наук, доцент, доцент кафедри підприємництва, корпоративної та просторової економіки, Донецький національний університет імені Василя Стуса ORCID: 0000-0001-8769-3636 victoria.klochkovska@gmail.com

\section{Клочковський О.В.}

кандидат економічних наук, доцент, доцент кафедри менеджменту та поведінкової економіки Донецький національний університет імені Василя Стуса ORCID: 0000-0002-2839-393X alex.klochkovsky@gmail.com

\section{СУЧАСНІ ОСОБЛИВОСТІ ОПОДАТКУВАННЯ В УКРАЇНІ}

У статті розглянуто спеиифіку функиіонування української податкової системи. 3 ясовано, щчо ключовим урядовим завданням є покращення вітчизняного фіскального законодавства з метою формування сприятливого середовища для ведення бізнесу та приваблення інвесторів. Визначено сутність дефініції «податок», виокремлено прямі й непрямі види фіскальних зборів. Наведено групи доходів, за якими україниі відраховують прямі податки до бюджету. Встановлено, що непрямі податки включені в ціну продукту та сплачуються громадянами під час купівлі будь-якого товару чи послуги. Досліджено, що система оподаткування в Украйні представлена загальною і спрощеною формами. Окреслено важливість податку на доходи фізичних осіб, оскільки він слугує одним з головних джерел поповнення казни. Виявлено, щзо теперішні легітимні фіскальні зміни пов язані також з життєдіяльністю країн в умовах пандемії. Наголомено, що елементом економічних відносин України з іншими державами є обмін податковими даними на основі Конвенції про взаємну адміністративну допомогу у фіскальних справах стосовно уникнення подвійного оподаткування. Акцентовано, щуо Украйна, зв'язана умовами міжнародних домовленостей та кошторисними проблемами, зацікавлена у розвитку напряму прозорої сплати податків.

Ключові слова: податок, бізнес, підприємецьь, краӥни-члени ЄС, загальна система оподаткування, спрощена система оподаткування, пандемія.

Табл. - 1, Літ. - 9.

Постановка проблеми. Фіскальна система держави займає ключове місце в забезпеченні іiі господарського зростання, що безпосередньо відбивається на врегулюванні суспільного правопорядку, розвитку морально-культурних цінностей, захисті територіальної єдності, вирішенні сукупності соціально-економічних питань. Під час інтеграції у світовий простір Україна, на жаль, залишається на останніх позиціях за багатьма показниками життедіяльності в порівняні з іншими європейськими сусідами. Значну роль при цьому відіграє недосконалість вітчизняного механізму оподаткування [1]. 
Важливим обов`язковим платежем з українців $є$ податок на доходи фізичних осіб, що утворює бюджетні надходження з їх перерозподілом між державою й населенням. Кількість громадян, які його сплачують, найбільша. В сьогоденних реаліях формування соціально-спрямованої економіки нагальним питанням виступає пошук шляхів удосконалення національної фіскальної політики. Ситуація загострюється через економічну нестабільність в умовах високого ступеня тінізації, уникнення громадянами сплати обов'язкових зборів та суттєве розділення між рівнем доходів серед різних прошарків.

Податкова система $\epsilon$ одним із найбільш дійових засобів впливу на розвиток господарського сектору, а це - поява нових робочих місць, зменшення рівня безробіття, зростання розміру надходжень до бюджету тощо. Законодавчо визначено [2], що юридичні та фізичні особи у власній діяльності мають право обирати загальну або спрощену фіскальну систему, кожній з яких притаманні свої привілеї та недоліки. Урядова податкова стратегія виявляє місце бізнесу у відповідних стосунках з державою, його роль у співробітництві 3 покупцями, посередниками в процесі обліку взаєморозрахунків, що свідчить про необхідність проведення наукових досліджень, спрямованих на вивчення стану фіскальної галузі.

Аналіз останніх досліджень і публікацій. Складнощі в оподаткуванні бізнесу досліджено такими закордонними вченими як А. Базо, М. Кассон, Д. Кірбі, А. Клемм, Дж. Рейд та ін. Чисельні наукові праці вітчизняних економістів, серед яких Ф. Бутинець, О. Василик, А. Гальчинський, Ю. Іванов, М. Крупка, М. Кучерявенко, О. Лобанов, М. Слатвинська, С. Юрій присвячені визначенню теоретичних основ у фіскальному секторі та державному регулюванні підприємництва. Вчені О. Молдован, Л. Демиденко, П. Лайко, М. Перерви, О. Безкровний дискутують на тему переваг і недоліків вітчизняного податкового законодавства, вивчають алгоритм відтворення фіскальної політики. Попри суттєву кількість академічних досліджень з обраного напряму, подальшого розкриття, на нашу думку, вимагають питання щодо виявлення специфіки функціонування вітчизняного податкового механізму в умовах реформування законодавчої бази.

Формулювання цілей статті. Метою статті $є$ з ясування особливостей стягнення обов язкових платежів до бюджету 3 доходів громадян, ознайомлення 3 сучасними загальною та спрощеною системами оподаткування, виявлення переваг і недоліків кожної з них, а також оцінка застосування окремих податкових реформ СС в Україні.

Викладення основного матеріалу. На соціально-економічне зростання будь-якої країни впливає чимало економічних чинників, серед яких вагома роль належить саме процесу оподаткування. Важливим завданням держави є удосконалення фіскальної системи з метою створення сприятливого податкового середовища. Кожний уряд будує власний податковий механізм з легітимно затвердженими об'єктом, базою, структурою податкових пільг і відрахувань [3].

За експертними дослідженнями близько 90 \% українців безпосередньо не зіткалися зі сплатою податкових зобов'язань, тому більшість 3 них недостатньо обізнана $з$ приводу визначення джерел фінансування державного бюджету, хоча мова йде про їх власні гроші. Наймані працівники найбільш зацікавлені у з'ясуванні суми, перерахованої їм на руки, «чистої» заробітної плати. Стосовно платежів з неї, вважається, що це турбота роботодавця або відділу бухгалтерії. Насправді вся фінансова система країни спирається на невеличкі внески робітників. Саме на ці кошти утримують величезний державний механізм, здійснюють закупівлі та усі соціальні розрахунки. На податки громадян функціонує «безкоштовна» медична та освітня системи, сплачуються пенсії, стипендії, зарплата бюджетним працівникам. Отже, збільшення кошторисних видатків за 
визначеними напрямами можливе лише через процентне зростання фіскальних відрахувань 3 прибутків українців.

Наведемо таке визначення податку: це обов`язковий збір з доходів населення в державну скарбницю. Розрізняють прямі та непрямі види податків. Прямим збором є процентне відрахування з певної грошової суми (платник та налогоносій один і той самий), непрямим - частина ціни товару або послуги, що входить до їх вартості (платник i налогоносій - різні). Платником непрямого податку є споживач (при купівлі), а налогоносієм - компанія, що збула продукт та відраховує податок державі. Відзначимо, що у розвинутих країнах $2 / 3$ фіскальних надходжень формують прямі податки й, навпаки, в державах з перехідною економікою аналогічна частка складається з непрямих зборів. Розрізняють декілька груп доходів, по яких українцями до бюджету сплачуються прямі податки [4]:

1) податок на доходи фізичних осіб (ПДФО) в обсязі $18 \%$; єдиний соціальний внесок на загальнообов' язкове державне страхування (ССВ) - $22 \%$; військовий збір (В3) - 1,5 \%. Їх перераховує роботодавець із зарплати найманих працівників;

2) податки з фізичних осіб-підприємців: єдиний податок (ЄП) та єдиний соціальний внесок (ССВ) за себе з урахуванням специфіки діяльності, а також ПДФО й В3 - при роботі на загальній системі оподаткування;

3) податки з пасивних доходів (банківських відсотків, роялті) - в сумі $18 \%$.

Непрямі збори враховані в ціну продукту та сплачуються усіма українцями під час купівлі будь-якого товару чи послуги: податок на додану вартість (ПДВ), акцизний збір, митне мито. Близько 1/4 частини заробітної плати, одержаної працівником, потрапляє у виді непрямих податків до бюджету. Найбільш вживаним з останніх є ПДВ, який сплачують покупці в обсязі 20 \% від собівартості товару (послуги). До речі, він був запроваджений у нашій країні в 1991 році. Акцизний збір стягується 3 тютюнових, алкогольних виробів та пального, а митом обкладаються імпортні товари.

На важливість ПДФО, як одного з базових джерел наповнення бюджетів різних рівнів, вказує той факт, що 3 кожним роком збільшується його обсяг та частка у зведеному кошторисі України. Доцільно зауважити, що ставка ПДФО в нашій державі у $18 \%$ є відносно невисокою. У деяких країнах-членах ЄС та в США верхня ії межа досягає 50 \%, в Австрії - навіть $55 \%$. Також в європейських країнах є досить гнучкі податкові ставки [4]. В багатьох 3 них значну роль у фіскальній системі відіграє покажчик «граничний дохід», що визначається як мінімальний розмір одержаного прибутку, з якого можливо сплачувати податок (наприклад, у Франції він дорівнює 9965 євро, в Німеччини - 9170 євро). Його величина залежить від кількості дітей, сімейного стану платника та способу оподаткування (єдина або роздільна система). Вітчизняна законодавча платформа забезпечує платників ПДФО наступними пільгами:

- виключенням зі списку загального оподатковуваного доходу за звітний період окремих видів доходів;

- одержанням фіскальної знижки;

- наданням податкової соціальної пільги (ПСП).

Метод визначення ставок ПДФО, що використовується в країнах $\mathrm{CC}$, позитивно характеризує їх фіскальні системи. На нашу думку, його доцільно застосовувати для модернізації відповідного українського законодавства, що сприятиме укріпленню принципу соціальної справедливості та покращенню податкової культури населення. Наявною відмінністю в оподаткуванні ПДФО у нас та закордоном є рівень фіскальної юрисдикції. А саме, ставки, алгоритм, стандарти оподаткування ПДФО в Україні затверджуються виключно на загальнодержавному рівні, тоді як в багатьох країнах ЄС 
(Бельгія, Данія, Фінляндія, Швеція) розрахунком ставок, за якими будуть оподатковуватися прибутки громадян, займаються органи місцевого адміністрування. В Естонії, Латвії, Норвегії ПДФО належить до категорії місцевих зборів. Вартий уваги той факт, що фіскальні системи європейських країн зорієнтовані на створення кінцевого доходу домогосподарств у такий спосіб, щоб у кожної фізичної особи після стягнення податків залишався дохід на фінансування всіх необхідних затрат стосовно задоволення власних потреб.

Як відомо, на соціально-економічне зростання країни впливає розвиток підприємництва, що потребує значних інвестицій [5]. Останні підтримують оборотність ресурсів. При цьому надійне та вигідне фіскальне законодавство у змозі привабити іноземних вкладників. 3 метою ефективного функціонування урядового механізму податкова політика має бути сприятливою та спрощеною, забезпечувати обов язкові надходження до бюджету в розмірах, необхідних для повної реалізації державних соціальних функцій [6].

Одним 3 найсуттєвіших моментів, на який спираються закордонні інвестори впродовж прийняття рішень щодо відкриття бізнесу в тій чи іншій країні, є фіскальна система держави поряд з умовами здійснення підприємницької діяльності та оцінкою загального економічного клімату. Головними податками, на які звертають увагу потенційні капіталовкладники, виступають податок на прибуток (ПП), податок на додану вартість, єдиний соціальний внесок, а також податок на майно. Цілком зрозуміло, що недостатньо високі обсяги фіскальних платежів та складнощі з їх розподіленням у змозі помітно зіпсувати інвестиційну привабливість будь-якої країни.

Відзначимо, що система оподаткування в Україні відповідно до Податкового кодексу [2] представлена двома формами (таблиця 1):

Таблиця 1 - Система оподаткування в Україні*

\begin{tabular}{|c|c|}
\hline Форма & Сутність \\
\hline Загальна & $\begin{array}{l}\text { Вміщує необхідність сплати всіх податків та зборів, } \\
\text { затверджених на законодавчому рівні; грунтується на сплаті } \\
\text { податку на прибуток; відсутні обмеження за видами } \\
\text { економічної діяльності, кількістю найманих працівників і } \\
\text { сумою доходу за рік }\end{array}$ \\
\hline Спрощена & $\begin{array}{l}\text { Створена з метою сприяння розвитку малого і середнього } \\
\text { підприємництва, що значно полегшує процес сплати } \\
\text { податків та визначення прибутків; передбачає } 4 \text { групи } \\
\text { платників податку та сплату єдиного податку; має } \\
\text { обмеження у застосуванні за кількістю працівників, рівнем } \\
\text { доходу, видами господарської діяльності }\end{array}$ \\
\hline
\end{tabular}

*Розроблено авторами на підставі [2]

Для фізичних та юридичних осіб, які під час реєстрації бізнесу не подали заяву про використання спрощеної системи, застосовується загальна система податкових стягнень. Вона надає підприємцям можливості ведення власної справи без обмежень, притаманних спрощеній фіскальній системі. Тут передбачено наявність книги обліку витрат/доходів, в якій відбиваються хронологічно всі господарські операції на підставі документів, що їх підтверджують. Оподаткування на загальній системі вміщує операційні доходи протягом звітного періоду. Доходом при цьому вважається чистий прибуток - різниця між валовим доходом та документально підтвердженими видатками, що безпосередньо стосуються його отримання. Останні є валовими витратами та підлягають амортизації. 
Обрання загальної системи оподаткування корисно для тих підприємців, що заробляють на різниці між купівлею-продажем. Їм необхідно сплачувати до бюджету 18 \% податку на прибуток (також для окремих видів діяльності використовується спеціальні ставки). Цей внесок перераховують компанії-резиденти, що одержують дохід на українській території та за кордоном, і фірми-нерезиденти, які отримають прибуток з українських джерел. Сума податку обчислюється методом коригування фінансового результату до оподаткування відповідно до українського стандарту бухгалтерського обліку або Міжнародних стандартів фінансової звітності. Якщо річний дохід фірми понад 1 млн грн, вона має сплачувати ПДВ.

Для фізичних та юридичних осіб, що обрали спрощену фіскальну систему, розрізняють 4 групи платників єдиного податку [7]:

1) передбачена для здійснення торговельних відносин на ринках i надання побутового обслуговування громадянам; сплачує СП та ССВ; ліміт річного обороту - 1 002000 грн;

2) підходить для ресторанного господарства, виробництва і збуту товарів, надання послуг населенню; сплачує ЄП та ЄСВ кожного місяця у фіксованій сумі; ліміт обороту за рік - 5004000 грн;

3) розрахована на надавання послуг без обмежень - виробництво, торгівля, ресторанний бізнес, перевезення; сплачує 5 \% СП від щорічного доходу та ССВ; ліміт річного обороту - 7002000 грн;

4) використовується підприємцями-аграріями та іноземними вкладниками; визначає специфічні умови оподаткування для підприємств сільськогосподарського сектору. Розмір податку співвідноситься 3 категорією землі, іiі розташуванням та площею.

Отже, власник бізнесу має право власноруч обрати для себе спрощену фіскальну систему за умови відповідності легітимно зафіксованим критеріям [8]. Це стосується також нерезидентів. Наголосимо, що поміж юридичних осіб найбільш розповсюдженою $\epsilon$ третя група, яка потребує додержання ліміту річного обороту у встановленому обсязі. При дотриманні названої вимоги юридична особа може застосовувати фіксовану ставку $€$ С в розмірі 5 \% від доходу, якщо вона не $є$ платником ПДВ, або у розмірі 3 \% від доходу, якщо фірма перераховує ПДВ. В цілому, сплата одного податку суттєво покращує декларування прибутків та їх координування, що часто зацікавлює інвесторів на перших фазах бізнес-активності. Загалом, використовуючи спрощену систему, фізичні та юридичні особи звільняються від необхідності нарахування, сплати й відбиття у податковій звітності таких внесків як податок на прибуток, податок на додану вартість, податок на майно та частково від рентної плати.

Найбільш поширеними в українському бізнес-середовищі на сьогодні є загальна форма, друга і третя групи платників єдиного податку.

Сучасні податкові тренди, зрозуміло, пов язані з ерою пандемії. Завершення епохи офшорних зон та підвищення ступеню нагляду за трансфертним формуванням цін лише частина глобальних перетворень, спрямованих на боротьбу 3 тіньовими податками. Втілення принципу міжнародного обміну фінансовими даними відбирає можливість знаходження тихої «гавані» від податківців. У нашій країні це питання також загострюється через зростання бюджетного дефіциту.

Недосконалості фіскальної законодавчої бази застосовують у власних інтересах світові корпорації [9]. У 2013 р. Рада Організації економічного співробітництва та розвитку (ОЕСР) представила план BEPS. Останній пропонує реалізацію дій, зорієнтованих на боротьбу 3 порушеннями, що стосуються втілення особливих 
фіскальних правил та домовленостей про запобігання подвійному оподаткуванню. До проєкту входять більше ніж 100 держав, і з 2017 р. до них приєдналась наша країна.

У 2020 р. до української легітимної платформи було додано змін, що стосуються втілення окремих позицій цієї програми:

- необхідність розголошення фізичними особами-резидентами власної участі в іноземному бізнесі, який ними контролюється;

- лімітування затрат на грошові транзакції з пов'язаними особами;

- передбачення зловживань під час застосування угод щодо запобігання подвійному фіскальному стягненню;

- уникнення штучного обходження підтвердження статусу постійного представництва;

- удосконалення механізму регулювання трансфертних цін;

- додержання специфіки звітності у форматі держав для міжнаціональних груп компаній.

В цілому, запровадження світових правил оподаткування на вітчизняному рівні має стати новим стимулом для зростання зацікавленості податківців до підприємціврезидентів, що приймають учать в іноземному бізнесі, та до постійних представництв.

Суттєвим компонентом економічної міжнародної співпраці України сьогодні $\epsilon$ обмін податковими відомостями у планетарному масштабі на основі Конвенції про взаємну адміністративну допомогу у фіскальних справах для запобігання подвійному оподаткуванню. Протягом 2021 р. Україна має намір долучитись до загального стандарту звітності (CRS) OECP 3 метою покращення фіскально-інформаційного взаємозв 'язку з правовими системами інших країн.

На платформі міждержавного співробітництва, відповідних договорів та вимог світових фінансових структур, в ситуації нестачі бюджетних коштів, Україна продовжує дотримуватися напряму боротьби з ухиленнями від сплати податків. Вітчизняний уряд планує і далі обмежувати можливості для фіскального маневрування як для компаній, так і для окремих громадян.

Висновки. Наявна податкова модель будь-якої країни відбиває організаційну специфіку іiі соціально-економічного устрою. Механізм стягнення податку на доходи фізичних осіб в Україні та державах-членах ЄС досить схожий. Основними правилами функціонування європейської фіскальної системи $є$ прозорість, відкритість, спрямованість на розв`язання соціальних питань та на економічну мотивацію домогосподарств. В сучасних українських реаліях євроінтеграційного розвитку та створення соціально-орієнтованої ринкової економіки пріоритетним урядовим завданням $є$ поліпшення структури загальної й спрощеної системи оподаткування 3 урахуванням відповідних світових здобутків. Удосконалення вітчизняної фіскальної системи в частині стягнення обов'язкових зборів мають одночасно враховувати економічні інтереси держави й платників та усувати зацікавленість останніх щодо відповідних порушень. Визначено, що певним світовим каталізатором розвитку багатьох податкових тенденцій останнього року $є$ також пандемія. На нашу думку, зростання економіки України в умовах глобалізації є можливим в умовах подальшого формування ефективної соціально-спрямованої моделі стягнення обов язкових платежів 3 доходів фізичних та юридичних осіб з урахуванням потреб та інтересів держави. 


\section{СПИСОК ВИКОРИСТАНИХ ДЖЕРЕЛ}

1. Букреєва Д. С. Удосконалення механізму розвитку малого бізнесу в Україні: податково-інтеграційний аспект. Економічний простір. 2016. № 109. С. 85-97.

2. Податковий кодекс України / Верховна Рада України [Електронний ресурс]. - URL: http://zakon.rada.gov.ua/laws/show/580-19.

3. Безкровний О. В. Оподаткування малого та середнього бізнесу - від історії виникнення до сучасних перспектив розвитку. Східна Свропа: Економіка, бізнес та управління. 2017. № 6 (11). С. 280-285.

4. Податки в Україні: хто, за що і скільки платить державі [Електронний ресурс]. - URL: https://voxukraine.org/uk/podatki-v-ukrayini-hto-za-shho-i-skilki-platit-derzhavi/.

5. Демиденко Л. М., Демиденко В. І. Сдиний податок для суб'єктів малого підприємництва: протиріччя та перспективи. Финансовые услуги. 2017. № 6. С. 12-15.

6. Про внесення змін до Податкового кодексу України щодо вдосконалення адміністрування податків, усунення технічних та логічних неузгодженостей у податковому законодавстві: Закон України від 16.01.2020 № 466-IX. База даних «Законодавство України» / BP України [Електронний ресурс]. - URL: https://zakon.rada.gov.ua/laws/show/466-20/conv.

7. Податкова система України: податок на прибуток і спрощена система оподаткування [Електронний ресурс]. - URL: https://dlf.ua/ua/podatkova-sistema-ukrayini-podatok-napributok-i-sproshhena-sistema-opodatkuvannya/.

8. Луценко I. С. Оподаткування платників єдиного податку в сучасних умовах впровадження податкової реформи [Електронний ресурc]. - URL: http://www.economy. in.ua/pdf/6 2020/24.pdf.

9. Податкові тренди 2021. Що змінилося у роботі податкової та як це вплине на бізнес і сплату податків. [Електронний ресурс]. - URL:https://www.epravda.com.ua/ columns/2021/02/12/670972/.

\section{REFERENCES}

1. Bukreieva, D. (2016). Udoskonalennia mekhanizmu rozvytku maloho biznesu v Ukraini: podatkovo-intehratsiinyi aspect. Ekonomichnyi prostir. № 109. P. 85-97.

2. Podatkovyi kodeks Ukrainy / Verkhovna Rada Ukrainy. - URL: http://zakon.rada. gov.ua/laws/show/580-19.

3. Bezkrovnyi, O. (2017). Opodatkuvannia maloho ta serednoho biznesu - vid istorii vynyknennia do suchasnykh perspektyv rozvytku. Skhidna Yevropa: Ekonomika, biznes ta upravlinnia. № 6 (11). P 280-285.

4. Podatky v Ukraini: khto, za shcho i skilky platyt derzhavi. - URL: https://voxukraine.org/uk/podatki-v-ukrayini-hto-za-shho-i-skilki-platit-derzhavi/.

5. Demydenko, L. (2017). Yedynyi podatok dlia subiektiv maloho pidpryiemnytstva: protyrichchia ta perspektyvy. Fynansovye usluhy. № 6. P. 12-15.

6. Pro vnesennia zmin do Podatkovoho kodeksu Ukrainy shchodo vdoskonalennia administruvannia podatkiv, usunennia tekhnichnykh ta lohichnykh neuzghodzhenostei $\mathrm{u}$ podatkovomu zakonodavstvi: Zakon Ukrainy vid 16.01.2020 № 466-IX. Baza danykh «Zakonodavstvo Ukrainy» / VR Ukrainy. - URL: https://zakon.rada.gov.ua/laws/show/46620/conv.

7. Podatkova systema Ukrainy: podatok na prybutok i sproshchena systema opodatkuvannia. URL: $\quad$ https://dlf.ua/ua/podatkova-sistema-ukrayini-podatok-na-pributok-i-sproshhenasistema-opodatkuvannya/. 
8. Lutsenko, I. (2020). Opodatkuvannia platnykiv yedynoho podatku v suchasnykh umovakh vprovadzhennia podatkovoi reformy [Elektronnyi resurs]. - URL: http://www.economy.in.ua/pdf/6_2020/24.pdf.

9. Podatkovi trendy 2021. Shcho zminylosia u roboti podatkovoi ta yak tse vplyne na biznes $i$ splatu podatkiv. - URL:https://www.epravda.com.ua/ columns/2021/02/12/670972/.

\section{Клочковская В.А.,Клочковский А.В.}

\section{СОВРЕМЕННЫЕ ОСОБЕННОСТИ НАЛОГООБЛОЖЕНИЯ В УКРАИНЕ}

В статье рассмотрена специифика функиионирования украинской налоговой системы. Определено, что ключевым государственным заданием служит улучшение отечественного фискального законодательства с иелью формирования благоприятной среды для ведения бизнеса и привлечения инвесторов. Выяснена сущность дефиниции «налог», выделены прямые и непрямые виды фискальных сборов. Представлены группы доходов, по которым украинцами перечисляются в бюджет прямые налоги. Установлено, что непрямые налоги заложены в стоимости продукта и оплачиваются гражданами во время купли-продажи товара или услуги. Обозначено, что система налогообложения в Украине содержит общую и упрощенную формы. Зафиксирована важность поступления в бюджет налога на доходы физических лии, поскольку он является одним из главных источников пополнения казны. Отображено, что сегодняшние легитимные фискальные изменения связаны также с жизнедеятельностью стран в условиях пандемии. Выявлено, что элементом экономических отношений Украины с другими государствами выступает обмен налоговыми данными на основании Конвенции о взаимной административной помощи в фискальных делах во избежание двойного налогообложения. Акцентировано, что Украина, связанная условиями международных договоренностей и нехваткой бюджетных средств, заинтересована в развитии направления прозрачной уплаты налогов.

Ключевые слова: налог, бизнес, предприниматель, страны-члень ЕС, общая система налогообложения, упрощенная система налогообложения, пандемия.

\section{Klochkovska, O. Klochkovskyi MODERN FEATURES OF TAXATION IN UKRAINE}

The article examined features of modern Ukrainian tax system. Clarified that main government task is to improve domestic fiscal legislation with creating a favorable environment for business development and attracting investors. Essence of the category of "tax" is defined, direct and indirect types of fiscal payments were displayed. The groups of incomes on which Ukrainians deduct direct taxes to the budget are resulted. Established that indirect taxes are included in the product and are paid by citizens at the time of bying of goods or service. Tax system in Ukraine is consisted from general and simplified form. The importance of paying personal income tax to budget noted, as this serves as one of main sources of filling of the latter. Current fiscal changes in the legislation are also connected with vital activity of countries in the conditions of a pandemic. It is reflected that an element of Ukraine's economic relations with other states is the exchange of tax data on basis of the Convention on Mutual Administrative Assistance in Fiscal Matters to Avoid Double Taxation. Thus, Ukraine, bound by the terms of international agreements and budget problems, is interested in supporting of development of transparent taxing payment.

Keywords: tax, business, entrepreneur, EU member states, general system of tax proposals, simplified system of tax proposals, pandemic. 